\title{
PENINGKATAN KOMPETENSI PENYUSUNAN PENELITIAN TINDAKAN KELAS (PTK) MELALUI DIKLAT MODEL IN ON IN
}

\section{IMPROVEMENT OF CLASSROOM ACTION RESEARCH COMPETENCE (PTK) THROUGH IN ON IN TRAINING MODEL}

\author{
Endang Fadli \\ Widyaiswara Ahli Madya Balai Diklat Keagamaan Bandung \\ Email: muhamadirfanfirdaus9@gmail.com
}

\section{Abstrak}

This paper presents the results of research on Substantive Technical Training for Promoting Competence Research Action Class VIII (DTSPK PTK VIII). The objective is to examine the implementation of DTSPK PTK VIII in on in model, more specifically to know the improvement of competence of compilation of Class Action Research paper (PTK). This research was conducted using case study method with the data collected through questionnaire, interview and documentation. This research concludes that the competence of DTSPK PTK VIII participants in the preparation of paper of PTK after following the in on model is good meaning DTSPK PTK VIII in on model can increase the competence of writing papers of PTK.

Keywords: training, classroom action research, competencies, sessions
Abstrak

Tulisan ini menyajikan hasil penelitian pada Diklat Teknis Substantif Peningkatan Kompetensi Penelitian Tindakan Kelas Angkatan VIII (DTSPK PTK VIII). Tujuannya adalah mengkaji pelaksanaan DTSPK PTK VIII model in on in yang lebih khususnya untuk mengetahui peningkatan kompetensi penyusunan karya tulis Penelitian Tindakan Kelas (PTK). Penelitian ini dilakukan dengan menggunakan metode studi kasus, yang data-datanya dikumpulkan melalui angket, wawancara dan dokumentasi. Penelitian ini menyimpulkan bahwa kompetensi peserta DTSPK PTK VIII pada penyusunan karya tulis PTK setelah mengikuti diklat model in on in adalah baik. Maka DTSPK PTK VIII model in on in dapat meningkatkan kompetensi penyusunan karya tulis PTK.

Kata kunci : diklat, penelitian tindakan kelas, kompetensi, sesi 


\section{PENDAHULUAN}

Guru memegang peran penting dalam upaya mencerdaskan kehidupan bangsa. Berbagai kegiatan yang bertujuan meningkatkan mutu, penghargaan dan kesejahteraannya telah dan akan terus dilakukan. Harapannya, mereka akan lebih mampu bekerja sebagai tenaga professional dalam melaksanakan tugas dan kewajibannya sebagai tenaga pendidik.

Salah satu upaya kebijakan pemerintah dengan adanya Peraturan Menteri Pendayagunaan Aparatur Negara dan Reformasi Birokrasi Nomor 16 Tahun 2009 tentang Jabatan Fungsional Guru dan Angka Kreditnya, Peraturan Menteri Pendidikan Nasional Nomor 35 Tahun 2010 Tanggal 1 Desember 2010 tentang Petunjuk Teknis Pelaksanaan Jabatan Fungsional Guru dan Angka Kreditnya, serta Peraturan Bersama Menteri Pendidikan Nasional dan Kepala Badan Kepegawaian Negara Nomor : 03/V/PB/2010 dan Nomor : 14 Tahun 2010 tentang Petunjuk Pelaksanaan Jabatan Fungsional Guru dan Angka Kreditnya. Pada prinsipnya bertujuan untuk membina karir kepangkatan dan profesionalisme guru.

Sebelum pertauran tersebut, publikasi ilmiah hanya untuk pangkat/golongan ruang Pembina (IV/a) ke atas, sedangkan setelah terbitnya peraturan tersebut, sekarang mulai Pangkat Golongan III/b guru dituntut sudah membuat Publikasi Ilmiah yang salah satunya adalah PTK.

Untuk meningkatkan kompetensi membuat PTK salah satu upayanya melalui diklat PTK model biasa/regular, namun upaya itu kurang optimal, salah satu terobosan yang dilakukan adalah melalui diklat model in on in.
Pada diklat ini, sebelum diklat dilaksanakan peserta wajib membuat proposal PTK sebagai persyaratan. Kemudian proposal tersebut diteliti, dan hasil yang diperoleh dari proposal tersebut ternyata peserta tidak kompeten membuat PTK, hal ini dibuktikan dengan perolehan skor ratarata dari 13 indikator adalah 0,96 (kurang).

Tulisan ini menyajikan hasil penelitian pada Diklat Teknis Substantif Peningkatan Kompetensi Penelitian Tindakan Kelas Angkatan VIII (DTSPK PTK VIII) dengan model in on in. Terutama apakah DTSPK PTK VIII model in on in dapat meningkatkan kompetensi peserta pada penyusunan karya tulis PTK?

\section{Kajian Pustaka}

\section{Diklat Model In On In}

Pendidikan dan pelatihan pada hakikatnya merupakan salah satu bentuk kegiatan dari program pengembangan sumber daya manusia (personal development). Pengembangan sumber daya manusia sebagai salah satu mata rantai (link) dari siklus pengelolaan personil dapat diartikan proses perbaikan staf melalui berbagai macam pendekatan yang menekankan realisasi diri (kesadaran), pertumbuhan pribadi dan pengembangan diri. Pengembangan mencakup kegiatankegiatan yang bertujuan untuk perbaikan dan pertumbuhan kemampuan (abilities), sikap (attitude), keterampilan (skill), dan pengetahuan anggota organisasi.

Menurut Notoatmodjo ${ }^{1}$ diklat selain untuk meningkatkan kemampuan staf

1 Soekidjo Notoatmodjo. 2009. Pengembangan Sumberdaya Manusia. Jakarta: Rineka Cipta, h. 27. 
yang menduduki suatu jabatan tertentu juga dilakukan untuk meningkatkan produktivitas kerja. Dengan peningkatan produktivitas kerja para pegawai/ karyawan organisasi yang bersangkutan akan memperoleh keuntungan. Pendapat Notoatmodjo tersebut menekankan betapa pentingnya diklat bagi pegawai/ karyawan dalam proses pencapaian tujuan atau keberhasilan organisasi. Kemampuan dan keterampilan pegawai dipandang sebagai modal yang sangat besar dalam peningkatan produktivitas kerja, Oleh karenanya diklat merupakan suatu hal yang seharusnya dilaksanakan secara terus-menerus dan berkesinambungan.

Hal senada dikemukakan The Trainer's Library dalam Soebagio Atmodiwirio adalah:

Seluruh kegiatan yang didesain untuk membantu meningkatkan pegawai memperoleh pengetahuan, ketrampilan dan meningkatkan sikap, perilaku yang dibutuhkan untuk melaksanakan pekerjaan dengan baik yang sekarang menjadi tanggung jawabnya sehingga tujuan organisasi dapat tercapai².

Sedangkan menurut Peraturan Pemerintah Nomor 101 Tahun 2000 tentang Pendidikan dan Pelatihan Jabatan Pegawai Negeri Sipil, disebutkan "Pendidikan dan pelatihan Jabatan Pegawai Negeri Sipil yang disebut Diklat adalah proses penyelenggaraan belajar mengajar dalam rangka meningkatkan kemampuan Pegawai Negeri Sipil"3. Pendidikan dan pelatihan

2 Soebagio Atmodiwirio. 2002. Manjemen Pelatihan. Jakarta: PT Ardadizya Jaya, h. 37.

${ }^{3}$ Annonimous. 2003. Peraturan Pemerintah Nomor 101 Tahun 2000 tentang Pendidikan dan Pelatihan Jabatan Pegawai Negeri Sipil. Jakarta: Sekretaris Negara RI, h. 2. kepegawaian juga merupakan bagian dari sebuah sistem pembinaan karier Pegawai Negeri Sipil yang bermakna pada pengembangan kepegawaian.

Dari beberapa pendapat diatas disimpulkan bahwa diklat adalah "serangkaian kegiatan yang didesain untuk meningkatkan pengetahuan, ketrampilan dan meningkatkan sikap, perilaku pegawai negeri sipil dalam menjalankan tugas sehingga tujuan organisasi dapat tercapai"

Pendidikan dan pelatihan sebagai bagian integral dari kebijakan personil dalam rangka pembinaan pegawai disamping sebagai sarana pembinaan yang bertujuan untuk meningkatkan kemampuan teknis, juga untuk memantapkan sikap mental pegawai. Pendidikan dan pelatihan merupakan alat untuk menyesuaikan antara tanggung jawab dan pekerjaan dengan kemampuan, keterampilan dan kecakapan serta keahlian dari pegawai. Kebijaksanaan organisasi pada umumya menyarankan agar setiap pegawai diberi kesempatan untuk melanjutkan pendidikan dan pengembangan kepribadian, sehingga dapat meningkatkan pengetahuan serta keterampilan yang pada akhirnya mampu berkompetisi, dalam hal ini adalah guru madrasah.

Adapun yang dimaksud dengan model in on in pada diklat ini yaitu model diklat yang pembelajarannya dilaksanakan beberapa sesi, sesi di kelas dan sesi di luar kelas (tempat kerjanya masing-masing) dengan proyek yang harus dilaksanakan dan proyek tersebut harus selesai setelah diklat itu pun selesai. Sesi in yang dimaksud adalah pembelajaran di kelas secara klasikal atau dalam arti in service training, pada sesi ini mereka diberikan tugas untuk dibahas 
bersama-sama pada sesi on kemudian. Adapun sesi on adalah pembelajaran praktik di tempat tugas mereka membahas tugas yang telah diberikan pada sesi in dan menyelesaikan tugas tersebut, pada sesi ini lebih tepatnya on job training. Dengan demikian DTSPK PTK VIII model in on in merupakan diklat berbasis proyek. Adapun proyeknya adalah berupa Laporan PTK yang harus selesai setelah diklat ini berahir.

\section{Penelitian Tindakan Kelas (PTK)}

Penelitian Tindakan Kelas (PTK) atau dalam istilah bahasa inggrisnya Classroom Action Research (CAR), yang pengertian secara leterleknya terdiri dari tiga suku kata. Pertama penelitian, yaitu menunjuk pada kegiatan mencermati suatu objek dengan menggunakan cara dan aturan metodologi tertentu untuk memperoleh data atau informasi yang bermanfaat dalam meningkatkan mutu suatu hal yang menarik minat dan penting bagi peneliti. Kedua tindakan, menunjuk pada suatu gerak kegiatan yang sengaja dilakukan dengan tujuan tertentu. Dalam PTK berbentuk rangkaian siklus kegiatan siswa. Ketiga kelas, yaitu sekelompok siswa yang dalam waktu yang sama, menerima pelajaran yang sama dari guru yang sama pula. Dalam hal ini tidak terikat pada pengertian ruang bangunan, tetapi dalam pengertian yang lebih spesifik ${ }^{4}$.

Menurut Hopkins ${ }^{5}$ penelitian kelas adalah penelitian yang mengkombinasikan prosedur penelitian dengan tindakan

4 Suharsimi Arikunto, et.al., 2008. Penelitian Tindakan Kelas. Jakarta: PT. Bumi Aksara, h. 2-3.

5 David Hopkins. 1993. A Teacher's Guide to Classroom Research. Philadelphia: Open University Press, h. 44. substantif, suatu tindakan yang dilakukan dalam disiplin inkuiri, atau suatu usaha seseorang yang memahami apa yang terjadi, sambil terlibat dalam sebuah proses perbaikan dan perubahan. Sedangkan Suharjono $^{6}$ menjelaskan PTK adalah penelitian tindakan untuk memperbaiki mutu praktik pembelajaran di kelasnya, sehingga berfokus pada proses belajar mengajar yang terjadi di kelas. Lebih singkat Aqib mendefinisikan PTK merupakan suatu pencermatan terhadap kegiatan yang sengaja dimunculkan, dan terjadi dalam sebuah kelas ${ }^{7}$.

Dari pengertian-pengertian di atas dapat disimpulkan PTK adalah penelitian yang dilakukan oleh guru di kelasnya sendiri melalui refleksi diri dengan tujuan untuk memperbaiki kinerjanya sehingga hasil belajar siswa meningkat.

Dari simpulan tersebut maka PTK merupakan ragam penelitian pembelajaran yang berkonteks kelas yang dilaksanakan oleh guru untuk memecahkan masalahmasalah pembelajaran yang dihadapi oleh guru, memperbaiki mutu dan hasil pembelajaran dan mencobakan hal-hal baru pembelajaran demi peningkatan mutu dan hasil pembelajaran.

Ada beberapa kriteria pokok dari PTK, yaitu: (1) An inquiry of practice from within (penelitian berawal dari kerisauan guru akan kinerjanya); (2) Self reflective inquiry (metode utama adalah refleksi diri, bersifat

${ }^{6}$ Suhardjono. 2009. Penelitian Tindakan Kelas dan Penelitian Tindakan Sekolah. Malang: Lembaga Cakrawala Indonesia bekerja sama dengan LP3 UM, h. 11 .

${ }^{7}$ Zainal Aqib. 2006. Penelitian Tindakan Kelas bagi Pengembangan Profesi Guru. Bandung: Yrama Widya, h. 13. 
agak longgar, tetapi tetap mengikuti kaidahkaidah penelitian); (3) Fokus penelitian berupa kegiatan pembelajaran; Tujuannya memperbaiki pembelajaran.

Dari kriteria tersebut tentunya dapat dibandingkan ciri-ciri PTK dengan penelitian kelas non-PTK. Guru dianggap paling tepat melakukan PTK yang sesuai dengan bidang studi keahlianya, karena (1) guru mempunyai otonomi untuk menilai kinerjanya, (2) temuan penelitian formal sering sukar diterapkan untuk memperbaiki pembelajaran, (3) guru merupakan orang yang paling akrab dengan kelasnya, (4) interaksi guru siswa berlangsung secara unik, dan (5) keterlibatan guru dalam berbagai kegiatan inovatif yang bersifat pengembangan mempersyaratkan guru mampu melakukan penelitian di kelasnya.

\section{METODOLOGI PENELITIAN}

Penelitian ini termasuk dalam jenis penelitian kualitatif yakni studi kasus pada Diklat Teknis Substantif Peningkatan Kompetensi Penelitian Tindakan Kelas Angkatan VIII di Kemenag Kabupaten Bandung Provinsi Jawa Barat. Teknik pengambilan data dilakukan melalui angket, wawancara, dan dokumentasi. Angket diberikan langsung kepada peserta diklat. Wawancara dilakukan dengan guru peneliti, guru observer, kepala sekolah, pengawas dan panitia diklat. Sementara dokumentasi dilakukan untuk menelusuri dokumen-dokumen penting sebagai bahan bukti untuk memperkuat penelitian tentang DTSPK PTK VIII di Kemenag Kabupaten Bandung. Sementara analisa data menggunakan langkah-langkah mereduksi data, kategorisasi data, menafsirkan data, memverifikasi dan menarik kesimpulan.

\section{HASIL DAN PEMBAHASAN}

\section{Setting Penelitian}

Penelitiaan ini dilaksanaan selama kegiatan DTSPK PTK VIII berlangsung ditambah 3 (tiga) minggu untuk menyelesaikan laporan, bertempat di Kemenag Kabupaten Bandung dari tanggal 9 September sampai dengan 20 November 2017 (selama 72 hari ditambah 21 hari ${ }^{8}$ ) tempat pembelajaran klasikal di SMA Al Marwah beralamat di Kampung Bojong Pulus Desa Sukasari Kecamatan Pameungpeuk Kabupaten Bandung.

Jumlah jam diklat sebanyak 108 jam diklat yang terdiri dari tiga kelompok, yakni kelompok dasar sebanyak 5 jam diklat, kelompok inti 98 jam diklat, dan kelompok penunjang 5 jam diklat.

Sesi 1 dilaksanakan secara in pada tanggal 9 s.d. 10 September 2016 Adapun pada tanggal 9 September 2016 materi yang disampaikan adalah Pengarahan Program, Building Learning Commitment (BLC), Kebijakan Pendidikan Agama dan Keagamaan, Kebijakan Kementerian Agama tentang Diklat Teknis, dan Konsep PTK. Adapun pada tanggal 10 September 2016 materi yang disampaikan adalah Proposal PTK.

Diantara tanggal 11 s.d. 13 September 2016 peserta belajar mandiri menyelesaikan tagihan proposal PTK.

Sesi 2 role 1 dilaksanakan secara in pada tanggal 14 s.d. 15 September 2016. Pada

\footnotetext{
${ }^{8}$ Berarti jumlah semuanya adalah 93 hari (3
} bulan lebih 3 hari). 
tanggal 14 September 2016 materi yang disampaikan adalah Praktek PTK mengenai penyusunan planning. Adapun pada tanggal 15 September 2016 materi yang disampaikan adalah pengembangan instrumen.

Sesi 2 role 1 dilaksanakan secara on pada tanggal 16 September s.d. 3 Oktober 2016 materi yang disampaikan adalah Praktek PTK mengenai Praktik Acting dan Observing untuk Pertemuan 1 siklus 1 dan Praktik Acting dan Observing untuk Pertemuan 2 Siklus 1.

Pada sesi 2 role 1 ini pembelajaran praktik dilaksanakan di tempat tugas peserta yang diobserver oleh guru observer, kepala sekolah, dan pengawas yang dibimbing oleh widyaiswara dengan sistim cluster. Masingmasing pertemuan disesuaikan dengan jadwal guru peneliti.

Sesi 2 role 2 dilaksanakan secara in pada tanggal 4 s.d. 5 Oktober 2016. Pada tanggal 4 Oktober 2016 materi yang disampaikan adalah Praktik Acting dan Observing untuk Pertemuan 3 siklus 1 . Adapun pada tanggal 5 Oktober 2016 materi yang disampaikan adalah Praktek Reflecting dan Merancang Planing untuk Siklus 2.

Sesi 2 role 2 dilaksanakan secara on pada tanggal 6 s.d. 23 Oktober 2016 materi yang disampaikan adalah Praktek PTK mengenai Praktik Acting dan Observing untuk Pertemuan 1 siklus 2 dan Praktik Acting dan Observing untuk Pertemuan 2 siklus 2.

Sama halnya seperti Pada sesi 2 role 1 , maka pada sesi 2 role 2 pembelajaran praktik dilaksanakan di tempat tugas peserta yang diobserver oleh guru observer, kepala sekolah, dan pengawas yang dibimbing oleh widyaiswara dengan sistim cluster. Masingmasing pertemuan disesuaikan dengan jadwal guru peneliti.
Sesi 2 role 3 dilaksanakan secara in pada tanggal 24 s.d. 25 Oktober 2016. Pada tanggal 24 Oktober 2016 materi yang disampaikan adalah Praktek PTK mengenai Praktik Acting dan Observing untuk Pertemuan 3 siklus 2. Adapun Pada tanggal 25 Oktober 2016 materi yang disampaikan adalah Praktik Reflecting dan merancang Planing untuk Siklus selanjutnya.

Diantara tanggal 26 Oktober 2016 s.d. 18 November 2016 peserta belajar mandiri menyelesaikan tagihan pengumpulan dan penganalisaan data.

Sesi 3 dilaksanakan secara in padatanggal 19 s.d. 20 November 2016. Pada tanggal 19 November materi yang disampaikan adalah Konsep dan Sistematika Laporan PTK. Adapun pada tanggal 20 November 2016 materi yang disampaikan adalah Praktek Penyusunan Laporan PTK, evaluasi program dan ujian.

Tiga minggu setelah tanggal 20 November 2016 (dead line tanggal 11 Desember 2016) peserta diberi tugas untuk menyelesaikan Laporan PTK. Hasil dari tugas tersebut di telaah dan diberi skor tiap indikatornya.

Gambaran umum profil peserta DTSPK PTK VIII dapat dilihat pada tabel di bawah ini.

Tabel 1.

Profil Peserta DTSPK PTK VIII

Kemenag Kabupaten Bandung 2016

\begin{tabular}{cccccc}
\hline $\begin{array}{c}\text { Jenis } \\
\text { Kelamin }\end{array}$ & Jml & Persentase & Golongan & Jml & Persentase \\
\hline Laki-laki & 13 & $35 \%$ & II/c & 1 & $2,7 \%$ \\
\hline Wanita & 24 & $65 \%$ & III/a & 2 & $5,4 \%$ \\
\hline & & III/b & 9 & $24,3 \%$ \\
\hline & & III/c & 16 & $43,3 \%$ \\
\hline & & III/d & 2 & $5,4 \%$ \\
\hline & & IV/a & 7 & $18,9 \%$ \\
\hline
\end{tabular}




\begin{tabular}{lccccc}
\hline $\begin{array}{l}\text { Lama } \\
\text { Kerja } \\
\text { (Tahun) }\end{array}$ & Jml & Persentase & Jenjang & Jml & Persentase \\
\hline $0-5$ & 1 & $2,7 \%$ & RA (TK) & 1 & $2,7 \%$ \\
\hline $6-10$ & 11 & $29,7 \%$ & Ml (SD) & 9 & $24,3 \%$ \\
\hline $11-15$ & 15 & $40,5 \%$ & $\begin{array}{c}\text { MTs } \\
\text { (SLTP) }\end{array}$ & 21 & $56,8 \%$ \\
\hline $16-20$ & 4 & $10,8 \%$ & $\begin{array}{c}\text { MA } \\
\text { (SLTA) }\end{array}$ & 6 & $16,2 \%$ \\
\hline $21-25$ & 4 & $10,8 \%$ & & & \\
\hline$>26$ & 2 & $5,4 \%$ & & & \\
\hline
\end{tabular}

Dari tabel 1 diketahui bahwa jumlah peserta 37 orang, Laki-laki 13 orang (35\%) dan wanita 24 orang (65\%). Dari 37 orang tersebut yang bukan PNS adalah 1 orang (2,7\%).

Ditinjau dari segi golongan, kebanyakan golongan III sebanyak 29 orang $(78,4 \%)$ Sisanya golongan II yaitu 1 orang $(2,7 \%)$ dan golongan IV sebanyak 7 orang $(18,9 \%)$. Pembiayaan DTSPK PTK VIII ini adalah swadaya dari peserta. Mencermati dari data ini, berarti kesadaran mereka untuk peningkatan mutu dan hasil pembelajaran relatif tinggi. Apalagi dengan adanya peserta golongan II, padahal menurut regulasi golongan II belum diwajibkan untuk menyusun KTI.

Lama kerja mereka mayoritas antara 6 - 15 tahun sebanyak 26 orang (70,2\%) sisanya adalah lama kerja 0 - 5 tahun sebanyak 1 orang (2,7\%), lama kerja 16 - 20 tahun sebanyak 4 orang $(10,8 \%)$, demikian juga sama halnya lama kerja 21 - 25 tahun sebanyak 4 orang $(10,8 \%)$

Peserta DTSPK PTK VIII tugas mengajarnya mayoritas pada jenjang MI dan MTs sebanyak 30 orang $(81,1 \%)$, sisanya 1 orang $(2,7 \%)$ pada jenjang RA dan 6 orang $(16,2 \%)$ pada jenjang MA.

\section{Kompetensi Penyusunan PTK Peserta DTSPK PTK VIII}

Untuk mengetahui kompetensi penyusunan PTK peserta DTSPK PTK VIII, analisis datanya mengacu pada pendapat Suharsimi Arikunto yakni dilakukan dengan alternatif jawaban yang bergradasi empat ${ }^{9}$ dengan klasifikasi jawaban "sangat baik" (skor 4), "baik" (skor 3), "cikup" (skor 2), dan "kurang" (skor 1).

Pada penelitian ini penulis menjabarkan kompetensi penyusunan PTK menjadi 16 indikator yaitu (1) masalah PTK; (2) tindakan; (3) rumusan judul; (4) latar belakang masalah; (5) rumusan masalah; (6) tujuan penelitian; (7) hipotesis penelitian; (8) manfaat penelitian; (9) kajian pustaka atau landasan teori; (10) setting penelitian; (11) prosedur penelitian atau langkahlangkah tindakan; (12) teknik pengumpulan data atau metode pengumpulan data; (13) teknik pengolahan data atau metode analisis data; (14) hasil dan pembahasan penelitian; (15) kesimpulan dan saran; dan (16) kelengkapan-kelengkapan administrasi penelitian atau lampiran-lampiran. Adapun pembahasannya adalah sebagai berikut.

\section{Kompetensi Pemahaman terhadap Masalah PTK}

Setiap penelitian yang akan dilakukan harus selalu berangkat dari masalah. Bila dalam penelitian telah dapat menemukan masalah yang betul-betul masalah, maka sebenarnya pekerjaan penelitian itu $50 \%$

\footnotetext{
${ }^{9}$ Suharsimi Arikunto. 2006. Prosedur Penelitian: Suata Pendekatan Praktik. Jakarta: Rineka Cipta, h. 239244.
} 
telah selesai ${ }^{10}$. Oleh karena itu menemukan masalah dalam penelitian merupakan pekerjaan yang tidak mudah.

Demikian halnya para peserta DTSPK PTK VIII, awalnya mereka kurang memahami masalah PTK. Ada yang memahami masalah penelitian, tetapisusah menemukan masalah PTK. Karena memang masalah dalam PTK berbeda dengan masalah penelitian lainnya.

Setelah pembelajaran maka kompetensi pemahaman para peserta terhadap masalah PTK, sebagaimana laporan PTK yang mereka susun, kompetensinya seperti pada tabel di bawah ini.

Tabel 2.

Kompetensi Pemahaman terhadap Masalah PTK

\begin{tabular}{lcc}
\hline & f & $\%$ \\
\hline kurang & 10 & 27.03 \\
\hline cukup & 7 & 18.92 \\
\hline baik & 12 & 32.43 \\
\hline sangat baik & 8 & 21.62 \\
\hline
\end{tabular}

Dari tabel 2 tersebut terlihat bahwa kompetensi pemahaman terhadap masalah PTK sebanyak 10 orang (27,03\%) kurang, 7 orang $(18,92 \%)$ cukup, 12 orang $(32,43 \%)$ baik dan 8 orang (21.62\%) sangat baik. Kompetensi secara keseluruhan untuk kompetensi pemahaman masalah PTK adalah baik hal ini terlihat dari nilai rataratanya 2.49 .

\section{Kompetensi Merumuskan Tindakan}

Hal yang perlu diperhatikan dalam penilaian karya tulis PTK adalah bahwa model/metode pembelajaran bukan seperti biasanya, tetapi harus cemerlang dan

10 Sugiyono. 2009. Metode Penelitian Pendidikan Pendekatan Kuantitatif, Kualitatif, dan R \& D. Bandung: Alfabeta, h. 52. terpusat pada proses, bukan semata-mata hasil ${ }^{11}$.

Model/metode yang dijadikan tindakan para peserta semula adalah model/metode pembelajaran yang sudah biasa dilakukan. Ada juga model/metode yang dijadikan tindakan mereka itu berbeda dengan apa yang sudah biasa dilakukan tapi kurang cemerlang.

Setelah pembelajaran maka kompetensi merumuskan tindakan para peserta, sebagaimana laporan PTK yang mereka susun, kompetensinya seperti pada tabel di bawah ini.

Tabel 3.

Kompetensi Merumuskan Tindakan

\begin{tabular}{lcc}
\hline & f & $\%$ \\
\hline kurang & 11 & 29.73 \\
\hline cukup & 7 & 18.92 \\
\hline baik & 12 & 32.43 \\
\hline sangat baik & 7 & 18.92 \\
\hline
\end{tabular}

Pada tabel 3 tersebut nampak bahwa kompetensi menemukan tindakan sebanyak 11 orang $(29,73 \%)$ kurang, 7 orang (18.92\%) cukup, 12 orang $(32,43 \%)$ baik dan 7 orang (18.92\%) sangat baik. Kompetensi secara keseluruhan mengenai menemukan tindakan adalah baik hal ini terlihat dari nilai rata-ratanya 2,41 .

\section{Kompetensi Merumuskan Judul}

Unsur judul dalam PTK harus mengandung tiga unsur, yaitu what (apa yang ditingkatkan), who (siapa yang ditingkatkan) dan how (bagaimana caranya meningkatkan).

Semula judul PTK yang mereka susun seperti penelitian non PTK. Sebagian ada

\footnotetext{
${ }^{11}$ Suharsimi, Op. Cit., 10-11.
} 
yang menyusun judul PTK tetapi kurang dari tiga unsur (what, who dan how).

Setelah pembelajaran maka kompetensi peserta dalam merumuskan judul, sebagaimana laporan PTK yang mereka susun, kompetensinya seperti pada tabel di bawah ini.

Tabel 4.

Kompetensi Merumuskan Judul

\begin{tabular}{lcc}
\hline & f & $\%$ \\
\hline kurang & 8 & 21.62 \\
\hline cukup & 3 & 8.11 \\
\hline baik & 16 & 43.24 \\
\hline sangat baik & 10 & 27.03 \\
\hline
\end{tabular}

Kompetensi tentang merumuskan judul terlihat pada tabel 4, nampak bahwa sebanyak 8 orang $(21,62 \%)$ kurang, 3 orang $(8,11 \%)$ cukup, 16 orang $(43,24 \%)$ baik dan 10 orang $(27,03 \%)$ sangat baik. Kompetensi secara keseluruhan mengenai merumuskan judul adalah baik hal ini terlihat dari nilai rata-ratanya 2,76 .

\section{Kompetensi Menyusun Latar Belakang Masalah (LBM)}

Menurut Suhardjono ${ }^{12}$ latar belakang masalah (LBM) PTK menjelaskan tentang pertama, masalah yang diteliti adalah benarbenar suatu masalah pembelajaran yang terjadi di kelasnya (di sekolahnya). Kedua, masalah yang akan diteliti adalah masalah penting dan mendesak untuk dipecahkan, serta dapat dilaksanakan dilihat dari segi ketersediaan waktu, biaya dan daya dukung lainnya.

Semula ungkapan LBM peserta berkenaan dengan masalah pendidikan yang umum dan tidak spesifik permasalahan PTK.

\footnotetext{
${ }^{12}$ Suhardjono, Op. Cit., 19.
}

Setelah pembelajaran maka kompetensi peserta menyusun LBM, sebagaimana laporan PTK yang mereka susun, kompetensinya seperti pada tabel di bawah ini.

Tabel 5.

Kompetensi Menyusun Latar Belakang Masalah

\begin{tabular}{lcc}
\hline & f & $\%$ \\
\hline kurang & 9 & 24.32 \\
\hline cukup & 8 & 21.62 \\
\hline baik & 14 & 37.84 \\
\hline sangat baik & 6 & 16.22 \\
\hline
\end{tabular}

Berkaitandengan kompetensimenyusun latar belakang masalah dapat lihat pada tabel 5, sebanyak 9 orang (24,32\%) kurang, 8 orang $(21,62 \%)$ cukup, 14 orang $(37,84 \%)$ baik dan 6 orang $(16,22 \%)$ sangat baik. Secara keseluruhan kompetensi mengenai menyusun latar belakang masalah adalah baik hal ini terlihat dari nilai rata-ratanya 2,46 .

\section{Kompetensi Menyusun Rumusan Masalah (RM)}

Rumusan masalah (RM) merupakan pertanyaan yang jawabannya akan dicari melalui PTK $^{13}$. RM dalam PTK adalah beberapa pertanyaan yang akan terjawab setelah tindakan selesai dilakukan ${ }^{14}$. Oleh Karena itu maka dalam RM terdapat unsurunsur kalimat tanya, bagaimana proses, bagaimana situasi, bagaimana hasilnya, dan dapat diukur.

Awalnya RM PTK yang mereka buat seperti penelitian non PTK. Kebanyakan RM mereka tidak tertuju pada proses, situasi dan hasil.

\footnotetext{
${ }^{13}$ Suhardjono, Ibid.

${ }^{14}$ Suharsimi, Op. Cit., 36.
} 
Setelah pembelajaran maka kompetensi peserta menyusun RM, sebagaimana laporan PTK yang mereka susun, kompetensinya seperti pada tabel di bawah ini.

Tabel 6.

Kompetensi Menyusun Rumusan Masalah

\begin{tabular}{lcc}
\hline & f & $\%$ \\
\hline kurang & 2 & 5.41 \\
\hline cukup & 5 & 13.51 \\
\hline baik & 18 & 48.65 \\
\hline sangat baik & 12 & 32.43 \\
\hline
\end{tabular}

Berkenaan dengan kompetensi menyusun rumusan masalah dapat lihat pada tabel 6, sebanyak 2 orang (5,41\%) kurang, 5 orang $(13,51 \%)$ cukup, 18 orang $(48,65 \%)$ baik dan 12 orang $(32,43 \%)$ sangat baik. Secara keseluruhan kompetensi mengenai menyusun rumusan masalah adalah sangat baik hal ini terlihat dari nilai rata-ratanya 3,08.

\section{Kompetensi Menyusun Tujuan Penelitian (TP)}

TP seyogyanya sejalan dengan $\mathrm{RM}^{15}$. Maka pernyataan TP harus berkenaan dengan hal-hal yang ditanyakan dalam RM, begitu juga urutannya harus sesuai dengan RM.

Pada proposal yang mereka susun untuk persyaratan diklat, TP yang mereka buat urutannya tidak sesuai dengan RM. Pernyataan TP PTK seperti pernyataan TP non PTK. Pernyataan TP tidak berkenaan dengan hal-hal yang dilaksanakan dalam kegiatan penelitian. Pernyataan TP cenderung pada tujuan tindakan.

Setelah pembelajaran maka kompetensi peserta menyusun TP, sebagaimana laporan

\footnotetext{
${ }^{15}$ Suharsimi, Ibid., h. 37.
}

PTK yang mereka susun, kompetensinya seperti pada tabel di bawah ini.

Tabel 7.

Kompetensi Menyusun Tujuan Penelitian

\begin{tabular}{lcc}
\hline & f & $\%$ \\
\hline kurang & 3 & 8.11 \\
\hline cukup & 6 & 16.22 \\
\hline baik & 9 & 24.32 \\
\hline sangat baik & 19 & 51.35 \\
\hline
\end{tabular}

Selanjutnya, berkenaan dengan kompetensi menyusun tujuan penelitian terlihat pada tabel 7 , sebanyak 3 orang $(8,11 \%)$ kurang, 6 orang $(16,22 \%)$ cukup, 9 orang $(24,32 \%)$ baik dan 19 orang (51,35\%) sangat baik. Secara keseluruhan kompetensi mengenai menyusun tujuan penelitian adalah sangat baik hal ini terlihat dari nilai rata-ratanya 3,19.

\section{Kompetensi Menyusun Hipotesis Penelitian (HP)}

Dalam berbagai literatur tidak ada yang menyatakan secara tegas bahwa HP dalam PTK harus ada. Dalam PTK tidak ada HP tidak salah, tetapi apabila dalam PTK ada HP itu pun tidak disalahkan, dengan kata lain lebih baik.

Peneliti dalam hal ini sebagai fasilitator pada DTSPK PTK VIII memasukan materi HP dan mewajibkan kepada peserta agar mencantumkan HP pada laporan PTK mereka, karena berkenaan dengan proses pembelajaran. Adapun pada penelitian mereka selanjutnya selain pada DTSPK PTK VIII, itu dikembalikan pada mereka.

Seperti kelemahan pada indikator lainnya, umumnya pernyataan HP seperti pernyataan HP non PTK.

Setelah pembelajaran maka kompetensi peserta menyusun HP, sebagaimana laporan 
PTK yang mereka susun, kompetensinya seperti pada tabel di bawah ini.

Tabel 8.

Kompetensi Menyusun Hipotesis Tindakan

\begin{tabular}{lcc}
\hline & f & \% \\
\hline kurang & 3 & 8.11 \\
\hline cukup & 4 & 10.81 \\
\hline baik & 9 & 24.32 \\
\hline sangat baik & 21 & 56.76 \\
\hline
\end{tabular}

Berkenaan dengan kompetensi menyusun hipotesis tindakan terlihat pada tabel 8 , sebanyak 3 orang $(8,11 \%)$ kurang, 4 orang (10,81\%) cukup, 9 orang (24,32\%) baik dan 21 orang $(56,76 \%)$ sangat baik. Secara keseluruhan kompetensi mengenai menyusun hipotesis tindakan adalah sangat baik hal ini terlihat dari nilai rata-ratanya 3,30 .

\section{Kompetensi Menyusun Manfaat Penelitian (MP)}

Pada pernyataan MP setidaknya mengandung tiga unsur ${ }^{16}$, yaitu siswa, guru dan sekolah.

Kesalahan mereka kebanyakan mengenai pernyataan MP sepertipernyataan MP non PTK. Pada umumnya pernyataan MP hanya mengandung unsur siswa saja.

Setelah pembelajaran maka kompetensi peserta menyusun MP, sebagaimana laporan PTK yang mereka susun, kompetensinya seperti pada tabel di bawah ini.

Tabel 9.

Kompetensi Menyusun Manfaat Penelitian

\begin{tabular}{lcc}
\hline & f & \% \\
\hline kurang & 1 & 2.70 \\
\hline cukup & 3 & 8.11 \\
\hline baik & 12 & 32.43 \\
\hline sangat baik & 21 & 56.76 \\
\hline
\end{tabular}

\footnotetext{
${ }^{16}$ Suhardjono, Op. Cit., 20.
}

Dari tabel 9 terlihat bahwa kompetensi menyusun manfaat penelitian sebanyak 1 orang (2,70\%) kurang, 3 orang $(8,11 \%)$ cukup, 12 orang $(32,43 \%)$ baik dan 21 orang (56,76\%) sangat baik. Kompetensi secara keseluruhan untuk dalam hal menyusun manfaat penelitian adalah sangat baik hal ini terlihat dari nilai rata-ratanya 3,43.

\section{Kompetensi Menyusun Kajian Pustaka (KP) atau Landasan Teori (LT)}

Ciri khas PTK adalah tindakan, maka sudah pasti salah satu variabelnya adalah teori-teori mengenai tindakan yang berkenaan dengan model/strategi/metode dari tindakan tersebut ${ }^{17}$.

Pada proposal yang ditulis peserta, halhal yang penulis temukan diantaranya:

Pertama, peserta ada yang menjelaskan arti setiap kata, yang penuh dengan kutipan kamus yang tidak akan sampai pada pengertian yang dimaksud dalam judul. Contoh judul Upaya Meningkatkan Kreativitas Siswa melalui Metode Discovery. Maka pada bab II peserta membahas setiap kata (1) upaya, (2) meningkatkan, (3) kreativitas, (4) Siswa, (5) melalui, (6) metode, dan (7) discovery. Kedua, peserta hanya membahas salah satu teori dari dua variabel. Dan ketiga, peserta membahas teori kedua variabel tetapi tidak menghubungkan/mengaitkannya dengan tindakan.

Idealnya adalah membahas teori kedua variable, kemudian menghubungkan/ mengaitkan kedua variabel tersebut dengan tindakan.

Setelah pembelajaran maka kompetensi peserta menyusun $\mathrm{KP} / \mathrm{LT}$, sebagaimana

\footnotetext{
${ }^{17}$ Suhardjono, Ibid, h. 22.
} 
laporan PTK yang mereka susun, kompetensinya seperti pada tabel di bawah ini.

Tabel 10.

Kompetensi Menyusun Kajian Pustaka atau Landasan Teori

\begin{tabular}{lcc}
\hline & $\mathbf{f}$ & $\mathbf{\%}$ \\
\hline kurang & 7 & 18.92 \\
\hline cukup & 12 & 32.43 \\
\hline baik & 11 & 29.73 \\
\hline sangat baik & 7 & 18.92 \\
\hline
\end{tabular}

Pada tabel 10 tersebut nampak bahwa kompetensi menyusun kajian pustaka atau landasan teori sebanyak 7 orang (18,92\%) kurang, 12 orang $(32,43 \%)$ cukup, 11 orang (29,73\%) baik dan 7 orang (18.92\%) sangat baik. Secara keseluruhan kompetensi mengenai menyusun kajian pustaka atau landasan teori adalah baik hal ini terlihat dari nilai rata-ratanya 2.49 .

\section{Kompetensi Menyusun Setting Penelitian}

Sub bab setting penelitian menjelaskan mengenai lokasi penelitian, waktu penelitian dan gambaran tentang kelompok siswa atau subjek yang dikenai tindakan ${ }^{18}$. Dalam PTK tidak ada istilah populasi dan sampel.

Setelah peneliti cermati dari laporan PTK peserta, makakompetensi peserta menyusun setting penelitian, sebagaimana laporan PTK yang mereka susun, kompetensinya seperti pada tabel di bawah ini.

Tabel 11.

Kompetensi Menyusun Setting Penelitian

\begin{tabular}{lcc}
\hline & f & \% \\
\hline kurang & 3 & 8.11 \\
\hline cukup & 7 & 18.92 \\
\hline baik & 19 & 51.35 \\
\hline sangat baik & 8 & 21.62 \\
\hline
\end{tabular}

${ }^{18}$ Suharsimi, Op. Cit., 39.
Kompetensi tentang menyusun setting penelitian terlihat pada tabel 11, nampak bahwa sebanyak 3 orang (8,11\%) kurang, 7 orang (18,42\%) cukup, 19 orang (51,35\%) baik dan 8 orang $(21,62 \%)$ sangat baik. Kompetensi secara keseluruhan mengenai menyusun setting penelitian adalah baik hal ini terlihat dari nilai rata-ratanya 2,68.

\section{Kompetensi Menyusun Prosedur Penenlitian atau Langkah-langkah Tindakan}

Model PTK, Tindakan dilaksanakan minimal dua siklus. Yang satu siklusnya terdiri dari empat tahapan, yaitu (1) perencanaan, (2) pelaksanaan, pengamatan, dan (4) refleksi ${ }^{19}$.

Pada proposal yang mereka buat, tersirat bahwa pemahaman mereka tindakan yang dilaksanakan boleh hanya dengan satu siklus. Mereka pun memahaminya bahwa satu siklus adalah satu pertemuan. Padahal satu siklus terdiri dua atau tiga pertemuan.

Setelah peneliti cermati dari laporan PTK peserta, maka kompetensi peserta menyusun prosedur penelitian atau langkahlangkah tindakan, sebagaimana laporan PTK yang mereka susun, kompetensinya seperti pada tabel di bawah ini.

Tabel 12.

Kompetensi Menyusun Prosedur Penenlitian atau Langkahlangkah Tindakan

\begin{tabular}{lcc}
\hline & f & \% \\
\hline kurang & 11 & 29.73 \\
\hline cukup & 12 & 32.43 \\
\hline baik & 8 & 21.62 \\
\hline sangat baik & 6 & 16.22 \\
\hline
\end{tabular}

Berkaitandengan kompetensimenyusun prosedur penenlitian atau langkah-langkah tindakan terlihat pada tabel 12, sebanyak

\footnotetext{
${ }^{19}$ Suharsimi, Ibid., h. 16.
} 
11 orang $(29,73 \%)$ kurang, 12 orang $(32,43 \%)$ cukup, 8 orang $(21,62 \%)$ baik dan 6 orang $(16,22 \%)$ sangat baik. Secara keseluruhan kompetensi mengenai menyusun prosedur penenlitian atau langkah-langkah tindakan adalah baik hal ini terlihat dari nilai rataratanya 2,24 .

\section{Kompetensi Teknik Pengumpulan Data (TPD atau Metode Pengumpulan Data (MPD)}

Pada dasarnya ada empat cara yang mendasar untuk mengumpulkan data yaitu observasi (terbuka, terfokus, terstruktur dan sistematik), wawancara, dokumen (termasuk di dalamnya jurnal, catatan harian, surat-surat resmi, edaran, catatan rapat, catatan siswa, foto dll) dan materi audio visual ${ }^{20}$. Keempat cara tersebut ditujukan untuk menjelaskan mengenai informasi yang menyangkut indikator yang ada dalam tindakan.

Awalnya pada proposal yang mereka serahkan, TPD atau MPD yang mereka pakai mayoritas observasi dan wawancara.

Setelah peneliti cermati dari laporan PTK peserta, maka kompetensi peserta dalam TPD atau MPD, sebagaimana laporan PTK yang mereka susun, kompetensinya seperti pada tabel di bawah ini.

Tabel 13.

Kompetensi Teknik Pengumpulan Data atau Metode Pengumpulan Data

\begin{tabular}{lcc}
\hline & $\mathbf{f}$ & $\%$ \\
\hline kurang & 10 & 27.03 \\
\hline cukup & 13 & 35.14 \\
\hline baik & 9 & 24.32 \\
\hline
\end{tabular}

${ }^{20}$ Rochiati Wiriaatmaja, 2008. Metode Penelitian Tindakan Kelas. Bandung: Remaja Rosdakarya, h. 104122.
Berkenaan dengan kompetensi teknik pengumpulan data atau metode pengumpulan data terlihat pada tabel 13, sebanyak 10 orang $(27,03 \%)$ kurang, 13 orang $(35,14 \%)$ cukup, 9 orang $(24,32 \%)$ baik dan 5 orang $(13,51 \%)$ sangat baik. Secara keseluruhan kompetensi mengenai teknik pengumpulan data atau metode pengumpulan data adalah baik hal ini terlihat dari nilai rata-ratanya 2,24.

\section{Kompetensi Teknik Pengolahan Data atau Metode Analisis Data}

Pada PTK penyajian dan analisis data dilakukan sesuai rumusan masalah kemudian dikelompokkan menjadi satu.

Awalnya pada proposal yang mereka serahkan, analisis data yang mereka lakukan tidak sesuai rumusan masalah. Bahkan sebagian ada yang melakukannya menurut instrumen.

Kemudian, setelah peneliti cermati dari laporan PTK peserta, maka kompetensi peserta dalam menganalisis data seperti pada tabel di bawah ini.

Tabel 14.

Kompetensi Teknik Pengolahan Data atau Metode Analisis Data

\begin{tabular}{lcc}
\hline & f & \% \\
\hline kurang & 15 & 40.54 \\
\hline cukup & 14 & 37.84 \\
\hline baik & 7 & 18.92 \\
\hline sangat baik & 1 & 2.70 \\
\hline
\end{tabular}

Selanjutnya, berkenaan dengan kompetensi teknik pengolahan data atau metode analisis data terlihat pada tabel 14, sebanyak 15 orang (40,54\%) kurang, 14 orang $(37,84 \%)$ cukup, 7 orang $(18,92 \%)$ baik dan 1 orang $(2,70 \%)$ sangat baik. Secara keseluruhan kompetensi mengenai teknik pengolahan data atau metode analisis data 
adalah cukup hal ini terlihat dari nilai rataratanya 1,84 .

Dari keenembelas indikator, ternyata indikator kompetensi teknik pengolahan data atau metode analisis data memperoleh skor paling kecil.

\section{Kompetensi Menyusun Hasil dan Pembahasan Penelitian}

Pada bagian ini adalah menyajikan uraian masing-masing siklus dengan data lengkap mulai dari perencanaan, pelaksanaan, pengamatan, dan refleksi yang berisi penjelasan tentang aspek keberhasilan dan kelemahan yang terjadi ${ }^{21}$.

Setelah peneliti mencermati laporan PTK peserta, maka kompetensi peserta dalam menyajikan hasil dan pembahasan penelitian seperti pada tabel di bawah ini.

Tabel 15.

Kompetensi Menyusun Hasil

dan Pembahasan Penelitian

\begin{tabular}{lcc}
\hline & $\mathbf{f}$ & $\mathbf{\%}$ \\
\hline kurang & 16 & 43.24 \\
\hline cukup & 12 & 32.43 \\
\hline baik & 7 & 18.92 \\
\hline sangat baik & 2 & 5.41 \\
\hline
\end{tabular}

Berkenaan dengan kompetensi menyusun hasil dan pembahasan terlihat pada tabel 15 , sebanyak 16 orang $(43,24 \%)$ kurang, 12 orang $(32,43 \%)$ cukup, 7 orang $(18,92 \%)$ baik dan 2 orang $(5,41 \%)$ sangat baik. Secara keseluruhan kompetensi mengenai menyusun hasil dan pembahasan adalah cukup hal ini terlihat dari nilai rataratanya 1,86 .

\section{Kompetensi Menyusun Kesimpulan dan Saran}

Menyajikan simpulan hasil penelitian (potret kemajuan) harus sesuai dengan tujuan penelitian ${ }^{22}$.

Setelah peneliti mencermati laporan PTK peserta, maka kompetensi peserta dalam menyajikan kesimpulan dan saran seperti pada tabel di bawah ini.

Tabel 16.

Kompetensi Menyusun Kesimpulan dan Saran

\begin{tabular}{lcc}
\hline & $\mathbf{f}$ & $\boldsymbol{\%}$ \\
\hline kurang & 2 & 5.41 \\
\hline cukup & 4 & 10.81 \\
\hline baik & 19 & 51.35 \\
\hline sangat baik & 12 & 32.43 \\
\hline
\end{tabular}

Dari tabel 16 terlihat bahwa kompetensi menyusun menyusun kesimpulan dan saran sebanyak 2 orang $(5,41 \%)$ kurang, 4 orang $(10,81 \%)$ cukup, 19 orang $(51,35 \%)$ baik dan 12 orang $(32,43 \%)$ sangat baik. Kompetensi secara keseluruhan dalam hal menyusun menyusun kesimpulan dan saran adalah sangat baik hal ini terlihat dari nilai rataratanya 3,11 .

\section{Kompetensi Menyusun Kelengkapan- kelengkapan Administrasi Penunjang dan lampiran-lampiran}

Permasalahan administrasi sepertinya hal yang sepele tetapi terkadang menjadi penentu dalam penilaian angka kredit.

Macam-macam kelengkapan tersebut adalah : (1) halaman judul (cover), (2) lembar persetujuan dan pernyataan dari Kepala Sekolah/Madrasah yang menyatakan keaslian tulisan dari penulis,

\footnotetext{
${ }^{22}$ Suharsimi, Ibid.
}

${ }^{21}$ Suharsimi, Op. Cit., 83. 
(3) berita acara seminar (ditandatangani panitia dan Kepala Sekolah/ Madrasah), (4) pernyataan dari perpustakaan yang menyatakan bahwa makalah tersebut telah disimpan diperpustakaannya (jika perlu), (5) pernyataan keaslian tulisan yang dibuat dan ditandatangani oleh penulis yang disertai tanda tangan Kepala Sekolah/ Madrasah, dan (6) kata pengantar.

Adapun lampiran-lampiran tersebut adalah: (1) semua instrumen yang digunakan dalam penelitian (terutama lembar pengamatan), (2) contoh-contoh hasil kerja dalam pengisian/pengerjaan baik oleh guru maupun oleh siswa, (3) dokumen-dokumen pelaksanaan penelitian yang lain seperti foto kegiatan, (4) daftar hadir seminar, (5) riwayat hidup ketua peneliti dan anggota peneliti (bila perlu mencantumkan pengalaman penelitian yang relevan telah dihasilkan sampai saat ini).

Awalnya pada proposal yang mereka serahkan, melengkapi administrasi penunjang dan lampiran-lampiran hanya mencapai $25 \%$, setelah peneliti mencermati laporan PTK peserta maka pencapaiannya antara $76 \%-100 \%$.

Tabel 17.

Kompetensi Menyusun Kelengkapan-kelengkapan Administrasi Penelitian dan Lampiran-lampiran

\begin{tabular}{llc}
\hline & f & $\%$ \\
\hline $\begin{array}{l}\text { Penyusunan kelengkapan dipenuhi } \\
\text { sampai dengan 25\%. }\end{array}$ & 1 & 2.70 \\
\hline $\begin{array}{l}\text { Penyusunan kelengkapan dipenuhi } \\
\text { antara 26\% - 50\%. }\end{array}$ & 2 & 5.41 \\
\hline $\begin{array}{l}\text { Penyusunan kelengkapan dipenuhi } \\
\text { antara 51\% - 75\%. }\end{array}$ & 4 & 10.81 \\
\hline $\begin{array}{l}\text { Penyusunan kelengkapan dipenuhi } \\
\text { antara 76\% - 100\%. }\end{array}$ & 30 & 81.08 \\
\hline
\end{tabular}

Pada tabel 17 tersebut nampak bahwa kompetensi menyusun kelengkapan- kelengkapan administrasi penelitian dan lampiran-lampiran sebanyak 1 orang (2,70\%) kurang baik, 2 orang (5,41\%) cukup, 4 orang $(10,81 \%)$ baik dan 30 orang (81.08\%) sangat baik. Secara keseluruhan kompetensi mengenai menyusun kelengkapankelengkapan administrasi penelitian dan lampiran-lampiran adalah sangat baik hal ini terlihat dari nilai rata-ratanya 3,70.

Dari keenembelas indikator, ternyata indikator kompetensi melengkapi administrasi penunjang dan lampiranlampiran memperoleh skor paling besar (sangat baik). Menurut peserta, hal ini dimungkinkan sangat mudah karena sifatnya mengoleksi, melengkapi dan menyusun persyaratan ${ }^{23}$.

Jika dirata-ratakan kesemua kompetensi yang mencakup 16 indikator, maka skor rata-ratanya adalah 2,72 (baik). Dari semula 0,96 (kurang) dan setelah pembelajaran dan bimbingan skor menjadi 2,72 (baik), artinya ada peningkatan yang signifikan.

\section{PENUTUP}

Penelitian ini dapat disimpulkan: pertama, kompetensi peserta diklat pada penyusunan karya tulis ilmiah PTK setelah mengikuti diklat model in on in baik. Kedua, berdasarkan kesimpulan pertama, maka DTSPK PTK VIII model in on in dapat meningkatkan kompetensi penyusunan karya tulis ilmiah penelitian tindakan kelas.

Selanjutnya dari kesimpulan ini dapat direkomendasikan sebagai berikut : pertama, diklat model in on in dapat meningkatkan kompetensi guru dalam menyusun karya

${ }^{23}$ Hasil wawancara peserta pada tanggal 1 November 2016. 
tulis PTK. Lebih baiknya lagi model in on in ini dikembangkan lebih lanjut supaya berdaya guna dan berhasil guna. Kedua, sehubungan pada diklat ini peserta dituntut tagihan atau produk laporan penenlitian, maka waktu pelaksanaan diklat sebaiknya ditambah minimal 4 bulan.

\section{UCAPAN TERIMA KASIH}

Penulis sampaikan rasa terima kasih yang setinggi-tingginya kepada Kepala Balai Diklat Keagamaan Bandung beserta jajarannya yang telah memberikan motivasi dan semangat kepada penulis untuk selalu berkreasi dan berinovasi dalam mengembangkan kediklatan. Juga Bapak Kepala Kantor Kementerian Agama Kabupaten Bandung, Kepala Sub Bagian Tata Usaha, para Pengawas, para Kepala Madrasah, para Guru Observer, para panitia dan seluruh jajarannya atas semua dukungan yang diberikan. Dan juga eluruh sahabat dan teman sejawat yang telah sudi dan ikhlas membantu dan memberi sumbangan pemikirannya kepada penulis dalam penyusunan karya tulis ini hingga selesai pada waktunya. Hanya kepada Allah SWT jualah penulis sampaikan semoga semua kebaikan dan bantuan yang telah disumbangkannya mendapat balasan yang lebih baik dan lebih berharga, aamien.

\section{DAFTAR PUSTAKA}

Annonimous. (2003): Peraturan Pemerintah Nomor 101 Tahun 2000 tentang Pendidikan dan Pelatihan Jabatan Pegawai Negeri Sipil. Jakarta; Sekretaris Negara RI.
Aqib, Zainal. (2006): Penelitian Tindakan Kelas bagi Pengembangan Profesi Guru. Bandung; Yrama Widya.

Arikunto, Suharsimi. (2006): Prosedur Penelitian: Suata Pendekatan Praktik. Jakarta; Rineka Cipta.

Arikunto, Suharsimi et.al., (2008): Penelitian Tindakan Kelas. Jakarta; PT. Bumi Aksara.

Atmodiwirio, Soebagio. (2002): Manjemen Pelatihan. Jakarta; PT Ardadizya Jaya.

Hopkins, David. (1993): A Teacher's Guide to Classroom Research. Philadelphia; Open University Press.

Kelly, T.L. (1932): Scientific Method. Its Function in Research and in Education. New York; The Memillan Company.

Notoatmodjo,Soekidjo.(2009):Pengembangan Sumberdaya Manusia. Jakarta; Rineka Cipta.

Rummel, J.F. (1958): An Introduction to Research Procedure in Education. New York; Harper \& Brothers, Publisher.

Searles, H.L. (1948): Logic and Scientific Methods. New York; The Ronald Press Company.

Sugiyono. (2009): Metode Penelitian Pendidikan Pendekatan Kuantitatif, Kualitatif, dan R \& D. Bandung; Alfabeta.

Suhardjono. (2009): Penelitian Tindakan Kelas dan Penelitian Tindakan Sekolah. Malang, Lembaga Cakrawala Indonesia bekerja sama dengan LP3 UM.

Van Dalen, D.B. (1962): Understanding Educational Research: An Introduction. New York; McGraw-Hill Book Company Inc.

Wiriaatmaja, Rochiati. (2008): Metode Penelitian Tindakan Kelas. Bandung; Remaja Rosdakarya. 